Article

\title{
Effect of Oxygen Concentration and Tantalum Addition on the Formation of High Temperature Bismuth Oxide Phase by Mechanochemical Reaction
}

\author{
Hsiu-Na Lin ${ }^{1,2}$, May-Show Chen ${ }^{1,3,4}$, Yu-Hsueh Chang ${ }^{5}$, Pee-Yew Lee ${ }^{1,5, *}$ and \\ Chung-Kwei Lin $1,6, *$ (D) \\ 1 Research Center of Digital Oral Science and Technology, College of Oral Medicine, Taipei Medical University, \\ Taipei 110, Taiwan; tiffanylin1214@gmail.com (H.-N.L.); mayshowc@hotmail.com (M.-S.C.) \\ 2 Department of Dentistry, Chang Gung Memorial Hospital, Taipei 105, Taiwan \\ 3 Division of Prosthodontics, Department of Dentistry, Taipei Medical University Hospital, Taipei 110, Taiwan \\ 4 School of Dentistry, College of Oral Medicine, Taipei Medical University, Taipei 110, Taiwan \\ 5 Institute of Materials Engineering, National Taiwan Ocean University, Keelung 202, Taiwan; \\ 10255002@ntou.edu.tw \\ 6 School of Dental Technology, College of Oral Medicine, Taipei Medical University, Taipei, 110, Taiwan \\ * Correspondence: pylee@mail.ntou.edu.tw (P.-Y.L.); chungkwei@tmu.edu.tw (C.-K.L.); \\ Tel.: +886-2-24622192 (ext. 6425) (P.-Y.L.); +886-2-27361661 (ext. 5115) (C.-K.L.)
}

Received: 18 May 2019; Accepted: 14 June 2019; Published: 17 June 2019

check for updates

\begin{abstract}
High-temperature face-centered cubic bismuth oxide phase is a material of great interest given its unique properties. In the present study, $\alpha-\mathrm{Bi}_{2} \mathrm{O}_{3}$ and tantalum powders were used as the starting powders for the formation of high-temperature bismuth oxide phase via mechanochemical synthesis by high energy ball milling. $\left(\mathrm{Bi}_{2} \mathrm{O}_{3}\right)_{80}(\mathrm{Ta})_{20}$ and $\left(\mathrm{Bi}_{2} \mathrm{O}_{3}\right)_{95}(\mathrm{Ta})_{5}$ in weight concentrations were milled in either an oxygen-free argon-filled glove box environment or an ambient atmosphere to investigate the effects of oxygen concentration and tantalum addition. The as-milled powders were examined using X-ray diffraction, scanning electron microscopy with energy-dispersive spectroscopy, and differential scanning calorimetry to reveal the structural evolution. The experimental results showed that for $\left(\mathrm{Bi}_{2} \mathrm{O}_{3}\right)_{95}(\mathrm{Ta})_{5}$ powder mixtures milled within the glove box, tantalum gradually reacted with the $\alpha-\mathrm{Bi}_{2} \mathrm{O}_{3}$ phase and formed a $\beta-\mathrm{Bi}_{7.8} \mathrm{Ta}_{0.2} \mathrm{O}_{12.2}$ phase. For $\left(\mathrm{Bi}_{2} \mathrm{O}_{3}\right)_{80}(\mathrm{Ta})_{20}$ milled under the same conditions, Ta and $\alpha-\mathrm{Bi}_{2} \mathrm{O}_{3}$ mechanochemically reacted to form $\delta-\mathrm{Bi}_{3} \mathrm{TaO}_{7}$ and bismuth after 10 min of high energy ball milling, whereas milling $\left(\mathrm{Bi}_{2} \mathrm{O}_{3}\right)_{80}(\mathrm{Ta})_{20}$ under the ambient atmosphere with a much higher oxygen concentration accelerated the mechanochemical reaction to less than five minutes of milling and resulted in the formation of high-temperature $\delta-\mathrm{Bi}_{3} \mathrm{TaO}_{7}$ phase.
\end{abstract}

Keywords: bismuth oxide; phase transformation; high temperature metastable phase; mechanical milling; mechanochemical reaction

\section{Introduction}

Bismuth oxide is attracting increasing $R \& D$ interest due to its applications as a dental radiopacifying material [1-3] and an ionic conductor in solid oxide fuel cells [4-8]. Bismuth oxide exhibits four different crystal structures: $\alpha-, \beta-, \gamma-$, and $\delta$-phases. Monoclinic $\alpha-\mathrm{Bi}_{2} \mathrm{O}_{3}$ phase is in a stable phase at room temperature but transforms into an fcc $\delta$-phase at $729^{\circ} \mathrm{C}$, and melts into a liquid phase at $825^{\circ} \mathrm{C}$. Tetragonal $\beta$ - and bcc $\gamma$-phase are two possible metastable phases and appear at 650 and $639^{\circ} \mathrm{C}$, respectively, when cooling from high temperatures [9-11].

The $\delta$-phase is one of the best oxide ionic conductors, but it is stable at temperatures ranging from 729 to $825{ }^{\circ} \mathrm{C}$. Its fluorite-like structure induces $25 \%$ oxygen vacancies and cannot be stable at 
room temperature. Higher valence elements or smaller ionic radii are preferred to preserve the desired fluorite-like structure at room temperature. For example, $\mathrm{TiO}_{2}$ [12], $\mathrm{ZrO}_{2}$ [13], $\mathrm{HfO}_{2}$ [13], $\mathrm{SnO}_{2}$ [14], $\mathrm{Nb}_{2} \mathrm{O}_{5}[4,15], \mathrm{Ta}_{2} \mathrm{O}_{5}$ [11,15-17], $\mathrm{MoO}_{3}[15]$, and $\mathrm{WO}_{3}[12,15]$ with four to six valence electrons have been used to attempt to stabilize the fluorite-like structure at room temperature. In most reported research, starting oxide powders (usually $\alpha-\mathrm{Bi}_{2} \mathrm{O}_{3}$ with various amounts of the above-mentioned dopants) were mixed, ground, and annealed at desired temperatures with sufficient time to obtain the fcc $\delta$-phase.

The high-energy ball milling process [18-20], an efficient method used to prepare materials that are difficult to synthesize using conventional melting and casting techniques, is an alternative method to obtain the fluorite-like structure. Through mechanical alloying of dissimilar powders and mechanical milling of a single starting powder, nonequilibrium phases, which include amorphous materials, extended solid solutions, intermetallic compounds, metastable crystalline materials, nanocrystalline powders, and quasicrystals, can be synthesized [18,20-22]. If the mechanical energy produced during ball milling is absorbed by the milled materials and triggers a chemical reaction, mechanochemical synthesis occurs [23-25]. For instance, iron nanoparticles have been prepared via mechanochemical synthesis using iron chloride and sodium as the starting powders [26].

A few high-temperature bismuth oxide phases have been prepared via the high-energy ball milling process. For example, a $\delta-\mathrm{Bi}_{2} \mathrm{O}_{3}$ phase stabilized by hafnia and zirconia has been prepared using mechanochemical synthesis [13]. Castro and Palem [27] investigated the binary and ternary $\mathrm{Bi}_{2} \mathrm{O}_{3}-\mathrm{Nb}_{2} \mathrm{O}_{5}-\mathrm{Ta}_{2} \mathrm{O}_{5}$ oxide systems and fluorite-like $\mathrm{Bi}_{3} \mathrm{NbO}_{7}, \mathrm{Bi}_{3} \mathrm{TaO}_{7}$, and $\mathrm{Bi}_{3} \mathrm{Nb}_{1-\mathrm{x}} \mathrm{Ta}_{\mathrm{x}} \mathrm{O}_{7}$ phases were formed. Preparation of a metastable $\mathrm{Bi}_{6} \mathrm{Ti}_{5} \mathrm{O}_{22}$ phase was achieved by mechanochemical milling of $\mathrm{Bi}_{2} \mathrm{O}_{3}, \mathrm{TiO}_{2}$, and $\mathrm{WO}_{3}$ stoichiometric powder mixtures [12]. In addition, fully stabilized bcc $\gamma-\mathrm{Bi}_{2} \mathrm{O}_{3}$ phase was mechanosynthesized without any additive [28].

The aforementioned investigations involved milling $\alpha-\mathrm{Bi}_{2} \mathrm{O}_{3}$ with one or two other high valency oxides. Adding these oxides is expected to stabilize the high-temperature $\delta$-phase at room temperature and produce an excellent ionic conductor that can be used in solid oxide fuel cells. However, milling $\alpha-\mathrm{Bi}_{2} \mathrm{O}_{3}$ and tantalum powder mixture has not been reported in the literature and may lead to unexpected mechanochemical reaction. Only Hasanpour et al. [29] reported that mechanochemical synthesis of $\mathrm{Bi}_{-} \mathrm{Fe}_{3} \mathrm{O}_{4}$ nanocomposite was achieved by milling $\mathrm{Bi}_{2} \mathrm{O}_{3}$ and $\mathrm{Fe}$ powder mixtures. In the present study, we prepared a high-temperature fluorite-like $\delta-\mathrm{Bi}_{2} \mathrm{O}_{3}$ phase by milling $\alpha-\mathrm{Bi}_{2} \mathrm{O}_{3}$ and tantalum powder mixtures. The effects of tantalum addition and oxygen concentration, as well as structural evolution of the high-temperature bismuth oxide phase formation during ball milling, were investigated.

\section{Experimental Procedures}

Commercially available $\alpha-\mathrm{Bi}_{2} \mathrm{O}_{3}(99.9 \%)$ and tantalum (99.98\%) powders were used as the starting powders. We canned $4 \mathrm{~g}$ of the desired $\left(\mathrm{Bi}_{2} \mathrm{O}_{3}\right)_{80}(\mathrm{Ta})_{20}$ or $\left(\mathrm{Bi}_{2} \mathrm{O}_{3}\right)_{95}(\mathrm{Ta})_{5}$ compositions in weight percentage and $\mathrm{Cr}$ steel balls $(7 \mathrm{~mm}$ in diameter), which were selected to follow a ball-to-powder ratio of 5:1, into a SKH 9 high speed steel vial ( $40 \mathrm{~mm}$ in diameter and $50 \mathrm{~mm}$ in height). A SPEX 8000D shaker ball mill (Fisher Scientific, Ottawa, ON, Canada) was used for the high energy ball milling process, which was performed either under ambient atmosphere conditions or within an Ar-filled glove box, which had a total oxygen and water concentration of less than $100 \mathrm{ppm}$. The overall milling process lasted $3 \mathrm{~h}$ for $\left(\mathrm{Bi}_{2} \mathrm{O}_{3}\right)_{80}(\mathrm{Ta})_{20}$ and $10 \mathrm{~h}$ for $\left(\mathrm{Bi}_{2} \mathrm{O}_{3}\right)_{95}(\mathrm{Ta})_{5}$. The milling process was interrupted every $5 \mathrm{~min}$ for the first $30 \mathrm{~min}$ and interrupted every $30 \mathrm{~min}$ thereafter. Each interruption was followed by an equal length of time to cool the vial. An appropriate amount of the as-milled powder was extracted to examine the progress of the structural evolution.

The structural evolution during various milling stages were examined using X-ray diffraction (XRD), scanning electron microscopy (SEM), and differential scanning calorimetry (DSC). The XRD analysis was performed using a Bruker AXS GmbH-D2 PHASER diffractometer (Billerica, MA, USA) with monochromatic $\mathrm{Cu}-\mathrm{K} \alpha$ radiation $(30 \mathrm{kV}$ and $10 \mathrm{~mA})$. Phase percentages were determined by 
performing Rietveld fitting of the XRD patterns using XRD analysis software EVA (Bruker-AXS Diffrac EVA, Bruker, WI, USA). The cross-sectional views of as-milled powders were examined using a Nova NanoSEM 230 scanning electron microscope (FEI, Hillsboro, OR, USA) equipped with an EDAX Apollo X silicon drift detector EDS system (EDAX, Mahwah, NJ, USA) The DSC analysis was performed with a NETZSCH DSC 200 F3 differential scanning calorimeter (Gerätebau GmbH, Selb, Germany) where the sample was heated from room temperature to $300^{\circ} \mathrm{C}$ in a purified argon atmosphere at a heating rate of $20 \mathrm{~K} / \mathrm{min}$.

\section{Results and Discussion}

To understand the structural evolution during the ball milling process, we used XRD and cross-sectional observations using SEM. Figure 1 shows the XRD patterns as a function of milling time for the $\left(\mathrm{Bi}_{2} \mathrm{O}_{3}\right)_{80}(\mathrm{Ta})_{20}$ powder produced using high- energy ball milling within an argon-filled glove box environment. At the early stage of milling, up to the first $25 \mathrm{~min}$, crystalline peaks of the $\alpha-\mathrm{Bi}_{2} \mathrm{O}_{3}$ starting powder were observed (Figure 1a). The peaks' intensities decreased with increasing milling time. A similar trend was observed for tantalum. The diffraction peaks of tantalum, however, could be observed throughout the whole three-hour milling process. In addition, three new crystalline phases, which were $\alpha-\mathrm{Bi}_{2} \mathrm{O}_{4}$ (ICDD PDF card No. 50-0864), bismuth (ICDD PDF card No. 44-1246), and fluorite-like cubic $\delta-\mathrm{Bi}_{3} \mathrm{TaO}_{7}$ (ICDD PDF card No. 044-0202), formed after only $10 \mathrm{~min}$ of ball milling. The peaks' intensities of $\alpha-\mathrm{Bi}_{2} \mathrm{O}_{4}$ did not show noticeable differences throughout the milling process (from $10 \mathrm{~min}$ to three hours). The relative amount of bismuth increased with increasing milling time until the end of the three hours of milling. The formation of $\alpha-\mathrm{Bi}_{2} \mathrm{O}_{4}$, bismuth, and $\mathrm{Bi}_{3} \mathrm{TaO}_{7}$ suggests that tantalum reacts with $\alpha-\mathrm{Bi}_{2} \mathrm{O}_{3}$ particles and the mechanochemical reaction occurs after only $10 \mathrm{~min}$ of high energy ball milling. This shows a behavior similar to one previously reported in literature, in which milling $\alpha-\mathrm{Bi}_{2} \mathrm{O}_{3}$ and iron leads to the formation of $\mathrm{Bi}$ and $\mathrm{Fe}_{3} \mathrm{O}_{4}$ [29]. However, the relative peaks' intensities of $\mathrm{Bi}_{3} \mathrm{TaO}_{7}$ did not exhibit significant differences at the early stage of milling (i.e., the first 10-30 min). Slight decreases in the peaks' intensities and broadening of peaks was observed after long-term milling from $30 \mathrm{~min}$ to three hours (Figure 1b).

Figure 2 shows the cross-sectional SEM images of as-milled $\left(\mathrm{Bi}_{2} \mathrm{O}_{3}\right)_{80}(\mathrm{Ta})_{20}$ powder. Irregular grains with a wide particle size distribution were be observed at all milling stages starting from five minutes of milling (Figure 2a) to the end of three hours' milling (Figure 2h). Typically, the high-energy ball milling process can be divided into three different types of milling mechanisms, depending on the characteristics of starting powders: both ductile, ductile/brittle, and both brittle [20]. During ball-powder-ball collision, powder particles undergo deformation and/or a fracture process. Ductile powders usually form a lamellar structure at the beginning and result in homogeneous equiaxed particles at the end of milling. For a ductile/brittle system, brittle particles may fracture and are trapped within ductile interfaces and finally form a metal matrix composite with a uniform distribution of embedded brittle particles, whereas brittle/brittle particles are expected to fracture continuously into small particles and sometimes mechanical alloying between starting particles may occur. The present milling system consisted of $20 \mathrm{wt} \%$ ductile Ta and $80 \mathrm{wt} \%$ brittle $\alpha-\mathrm{Bi}_{2} \mathrm{O}_{3}$ particles. The densities of Ta and $\alpha-\mathrm{Bi}_{2} \mathrm{O}_{3}$ were 16.69 and $8.9 \mathrm{~g} / \mathrm{cm}^{3}$, respectively. The relative volume of ductile Ta is low and unable to trap all the fractured brittle $\mathrm{Bi}_{2} \mathrm{O}_{3}$ particles within the interfaces. This suggests that the powders were fractured and agglomerated repetitively throughout the milling process. No lamellar structure was observed. 


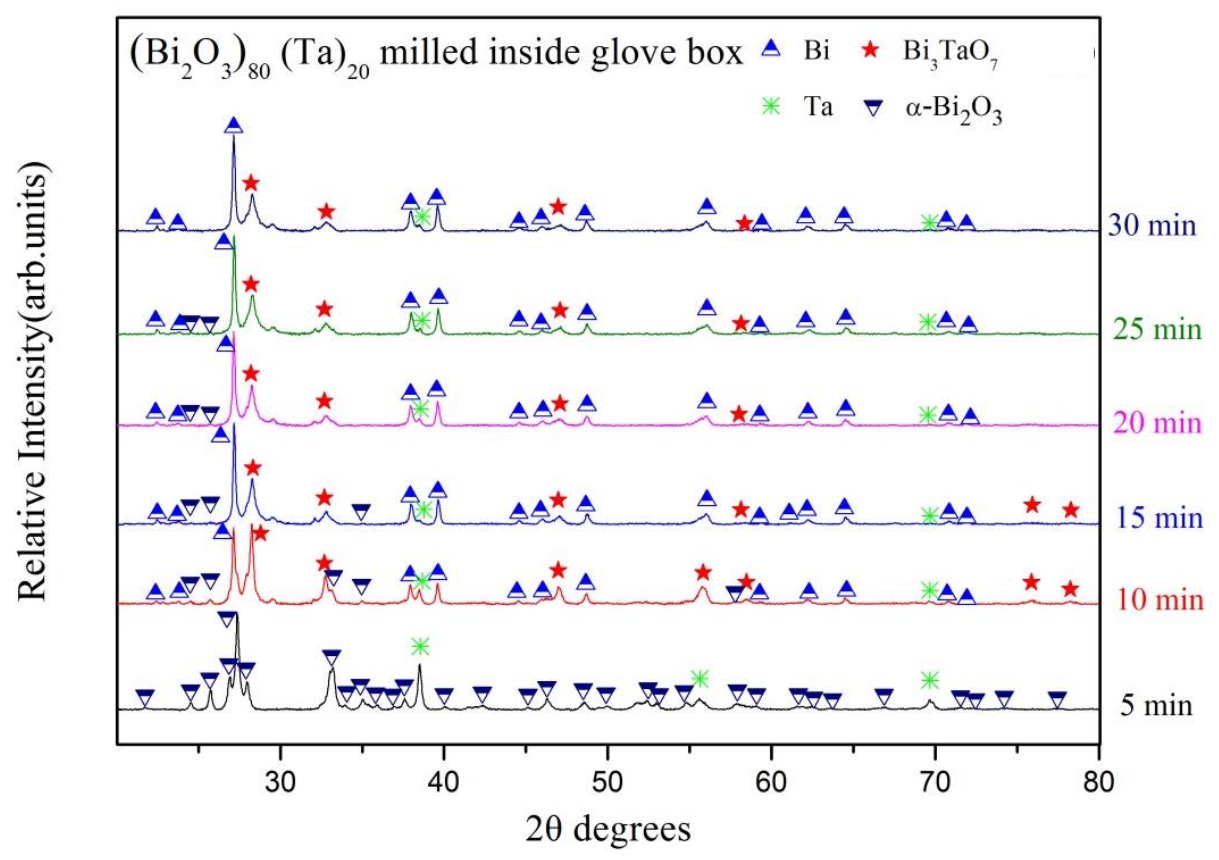

(a)

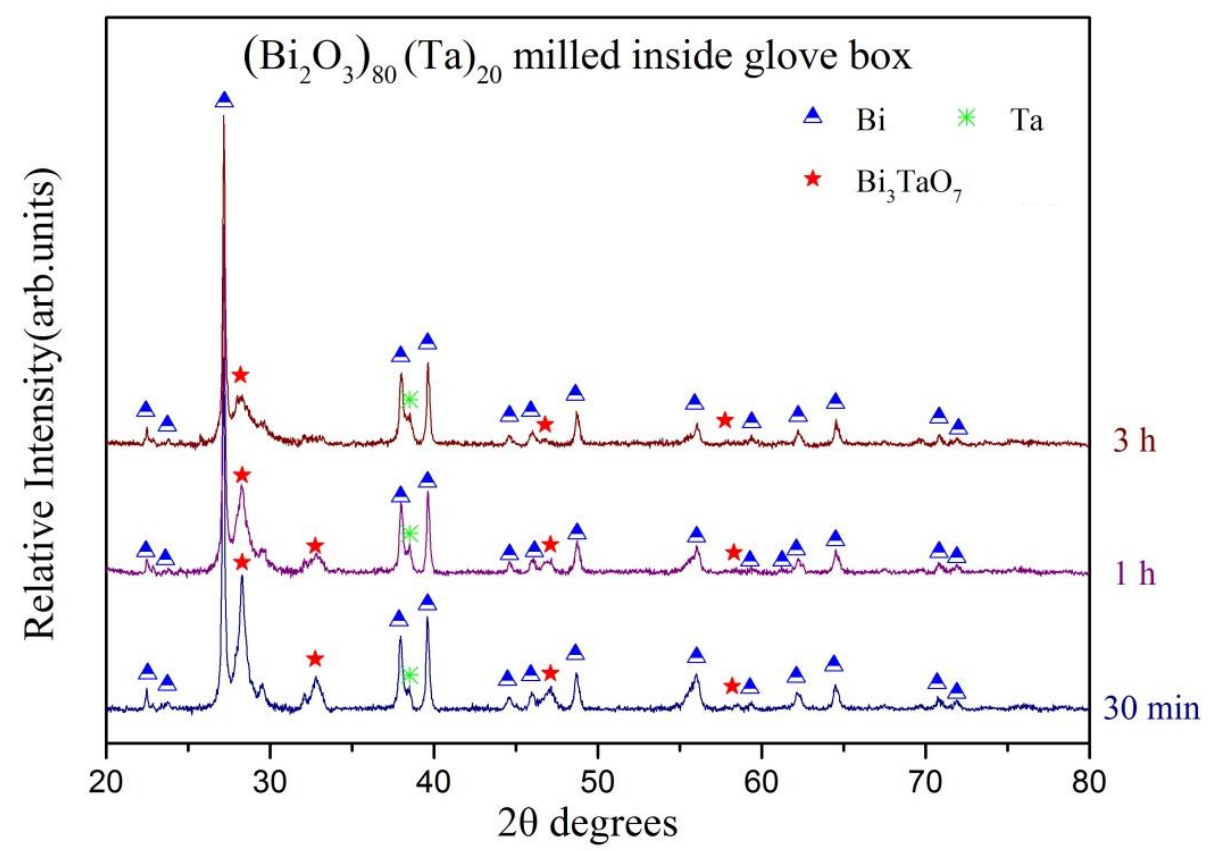

(b)

Figure 1. XRD patterns of $\left(\mathrm{Bi}_{2} \mathrm{O}_{3}\right)_{80} \mathrm{Ta}_{20}$ as a function of milling time under Ar-filled glove box conditions: (a) early stages of milling and (b) long-term milling.

To better demonstrate the structural evolution, the cross-sectional views with higher magnification of selective as-milled powders are shown in Figure 3. Notably, in the SEM photos obtained using backscattered electron images, the larger the atom, the brighter the area. As marked in Figure 3, the brightest area is bismuth, whereas the darkest area is tantalum, with the brightness of Bi-Ta-O being in between. Only the tantalum particle is close to being spherical in shape, whereas the others (Bi and $\mathrm{Bi}-\mathrm{Ta}-\mathrm{O}$ ) are irregular. This element distribution was confirmed using energy dispersive $\mathrm{X}$-ray (EDX) mapping. Figure 4 shows the three-hour as-milled powder with bismuth, tantalum, and oxygen 
mappings, where corresponding elements are uniformly distributed within the examined area, with the exception of some localized regions.
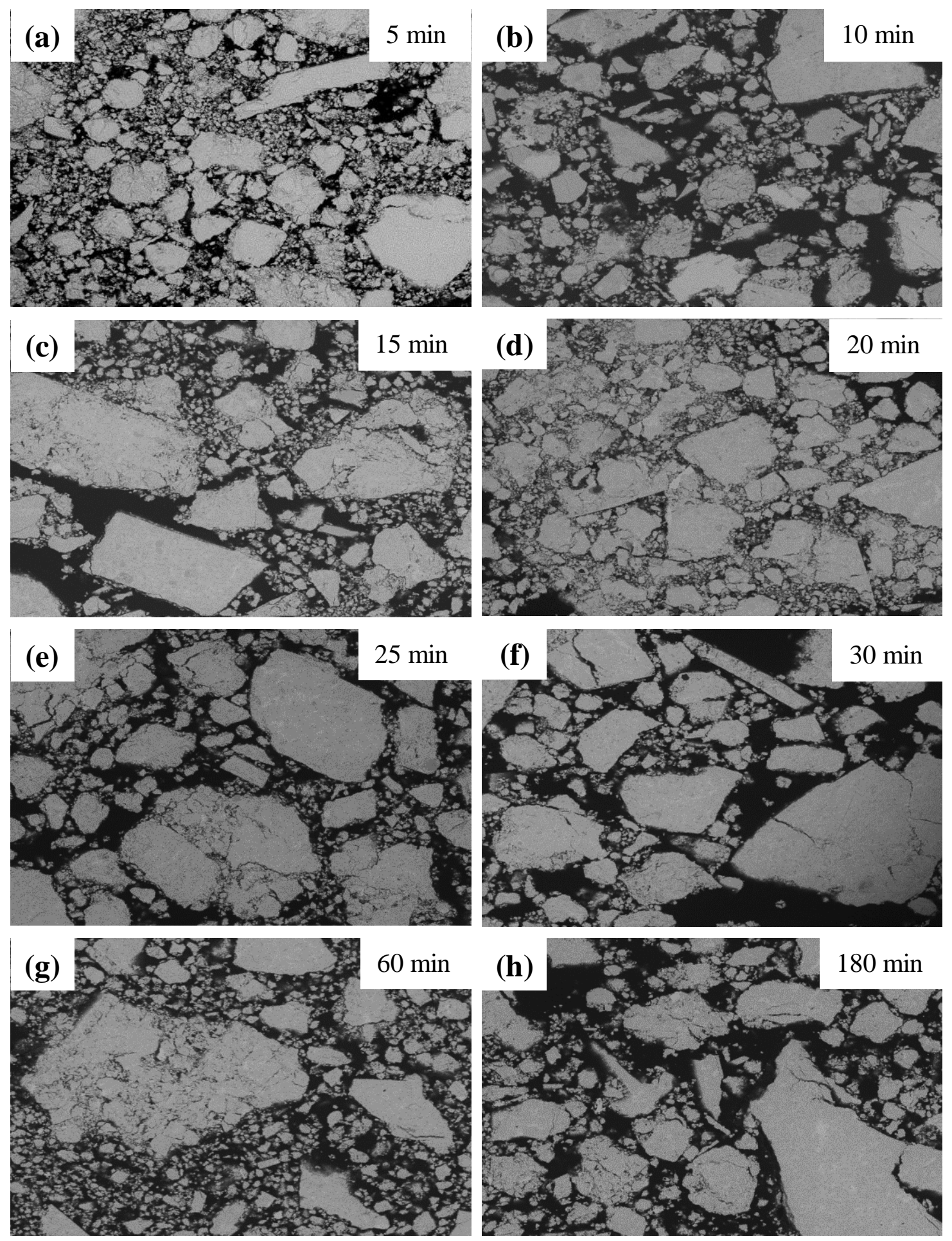

$30 \mu \mathrm{m}$

Figure 2. SEM images of $\left(\mathrm{Bi}_{2} \mathrm{O}_{3}\right)_{80} \mathrm{Ta}_{20}$ as a function of milling time under Ar-filled glove box conditions: (a) 5, (b) 10, (c) 15, (d) 20, (e) 25, (f) 30, (g) 60, and (h) $180 \mathrm{~min}$. 

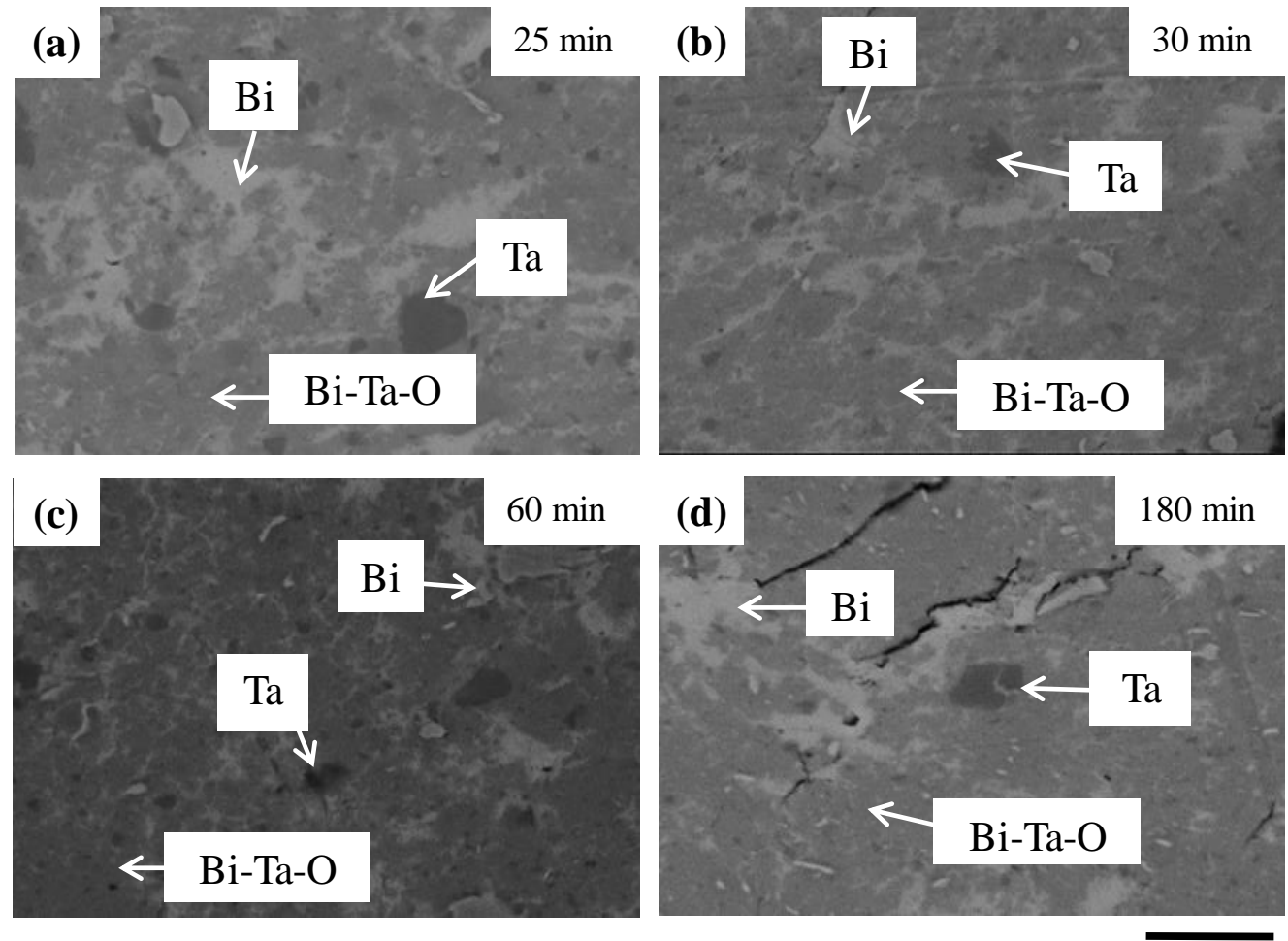

$3 \mu \mathrm{m}$

Figure 3. SEM images of $\left(\mathrm{Bi}_{2} \mathrm{O}_{3}\right)_{80} \mathrm{Ta}_{20}$ as a function of milling time under Ar-filled glove box conditions: (a) 25, (b) 30, (c) 60, and (d) $180 \mathrm{~min}$.
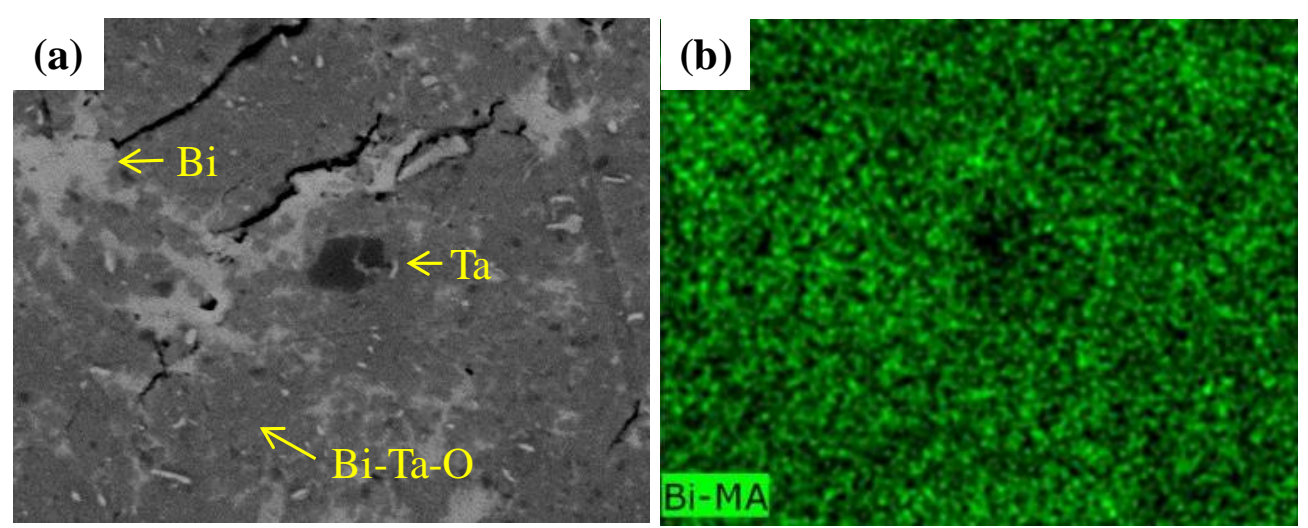

\section{(c)}

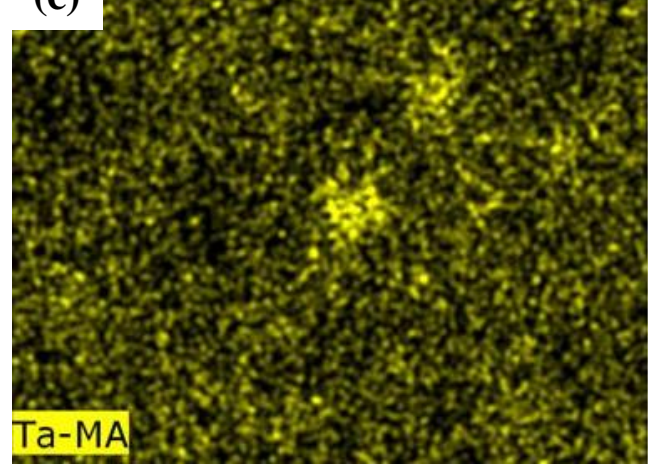

\section{(d)}

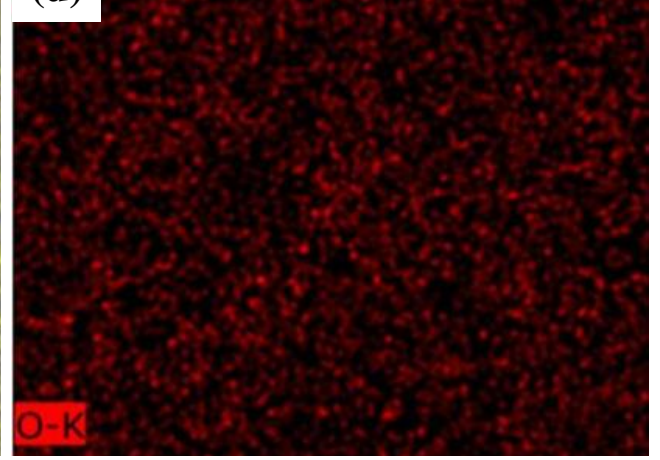

$3 \mu \mathrm{m}$

Figure 4. EDX mapping of $3 \mathrm{~h}$-as milled $\left(\mathrm{Bi}_{2} \mathrm{O}_{3}\right)_{80} \mathrm{Ta}_{20}$ powder. (a) SEM image; and mapping of element (b) $\mathrm{Bi}$; (c) Ta; (d) O. 
Figure 5 shows the DSC curves of $\left(\mathrm{Bi}_{2} \mathrm{O}_{3}\right)_{80}(\mathrm{Ta})_{20}$ powder after different milling times. An endothermic peak around $271.1^{\circ} \mathrm{C}$ (the melting point of bismuth) was observed for as-milled $\left(\mathrm{Bi}_{2} \mathrm{O}_{3}\right)_{80}(\mathrm{Ta})_{20}$ powders. The five-minute as-milled powder (black line in Figure 5) did not show a distinct endothermic peak, whereas the 10-min as-milled powder (red line in Figure 5) exhibited the largest endothermic peak at $272.8^{\circ} \mathrm{C}$, which corresponds to the melting of bismuth. The endothermic peak position did not show significant differences with long-term milling (30-180 min). The peak height, however, decreased with increasing milling time. This suggests that the amount of bismuth formed by mechanochemical reaction quickly reached a maximum during the early stage of milling (10 min) and gradually decreased with prolonged milling.

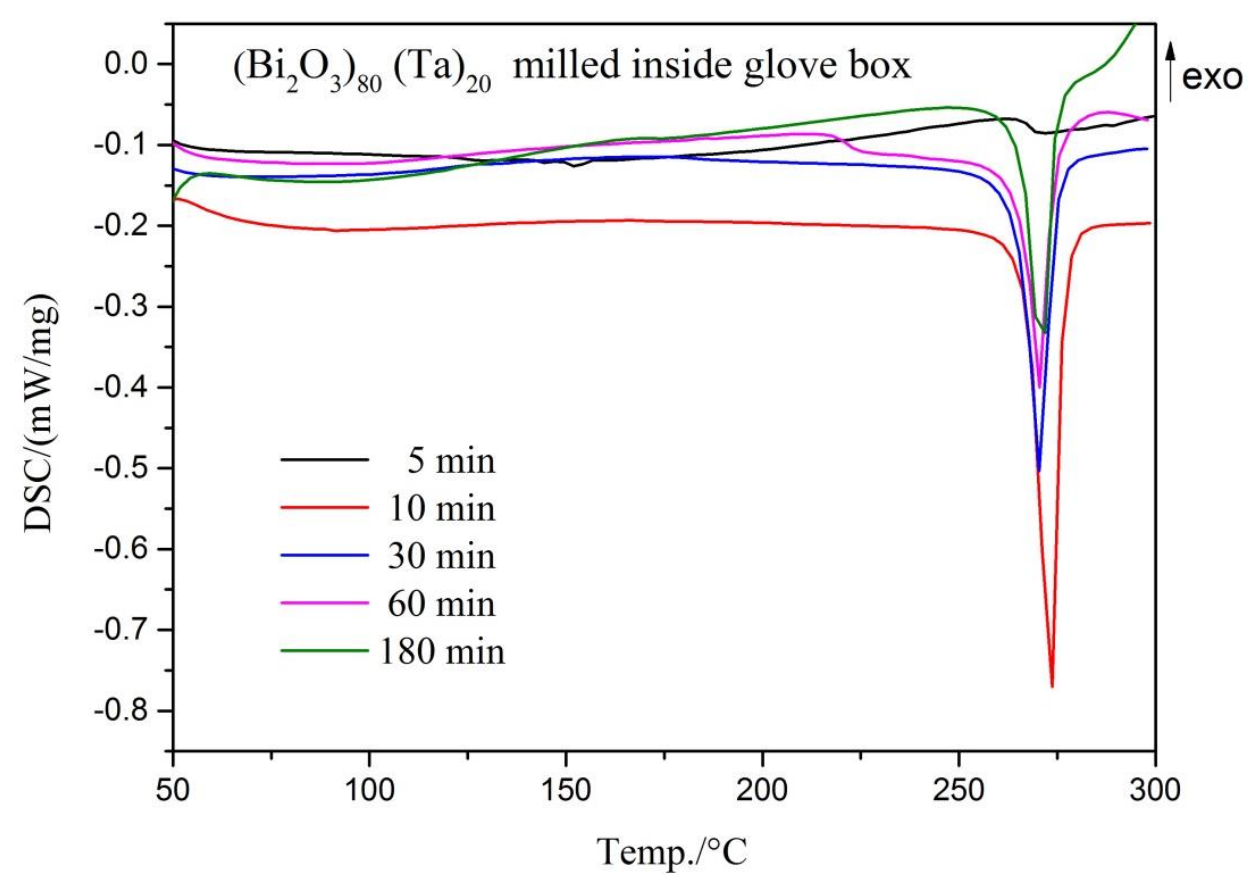

Figure 5. Differential SC curves of $\left(\mathrm{Bi}_{2} \mathrm{O}_{3}\right)_{80} \mathrm{Ta}_{20}$ after different milling times under Ar-filled glove box conditions.

The aforementioned high energy ball milling process is performed in a glove box, in which the total $\mathrm{O}_{2}$ and $\mathrm{H}_{2} \mathrm{O}$ concentrations are less than $100 \mathrm{ppm}$. Figure 6 shows the X-ray diffraction patterns of $\left(\mathrm{Bi}_{2} \mathrm{O}_{3}\right)_{80}(\mathrm{Ta})_{20}$ powder produced using high energy ball milling within an ambient environment in which the oxygen concentration is $\sim 20 \mathrm{vol} \%$. As shown in the bottom XRD pattern in Figure $6 \mathrm{a}$, formation of $\alpha-\mathrm{Bi}_{2} \mathrm{O}_{4}$, bismuth and $\delta-\mathrm{Bi}_{3} \mathrm{TaO}_{7}$ can be observed after merely 5 min of milling treatment (compared to that of 10 mins. within glove box, Figure 1a). This suggests that the mechanochemical reaction can be accelerated with the aid of oxygen. Similar to that of milling $\left(\mathrm{Bi}_{2} \mathrm{O}_{3}\right)_{80}(\mathrm{Ta})_{20}$ under glove box conditions, no significant differences in peaks' intensities for $\alpha-\mathrm{Bi}_{2} \mathrm{O}_{4}$ can be observed. Whereas, the diffraction peaks of bismuth reached a maximum after $10 \mathrm{~min}$ of milling. Those of the 30-min as-milled powder exhibited a maximum peak height for $\delta-\mathrm{Bi}_{3} \mathrm{TaO}_{7}$ phase. The crystalline peaks of $\alpha-\mathrm{Bi}_{2} \mathrm{O}_{3}$ diminished with milling time and became undistinguishable after $15 \mathrm{~min}$ of milling (30 min within glove box). However, those of tantalum persisted for up to $1 \mathrm{~h}$ of milling and could not be recognized at the end of $3 \mathrm{~h}$ milling. 


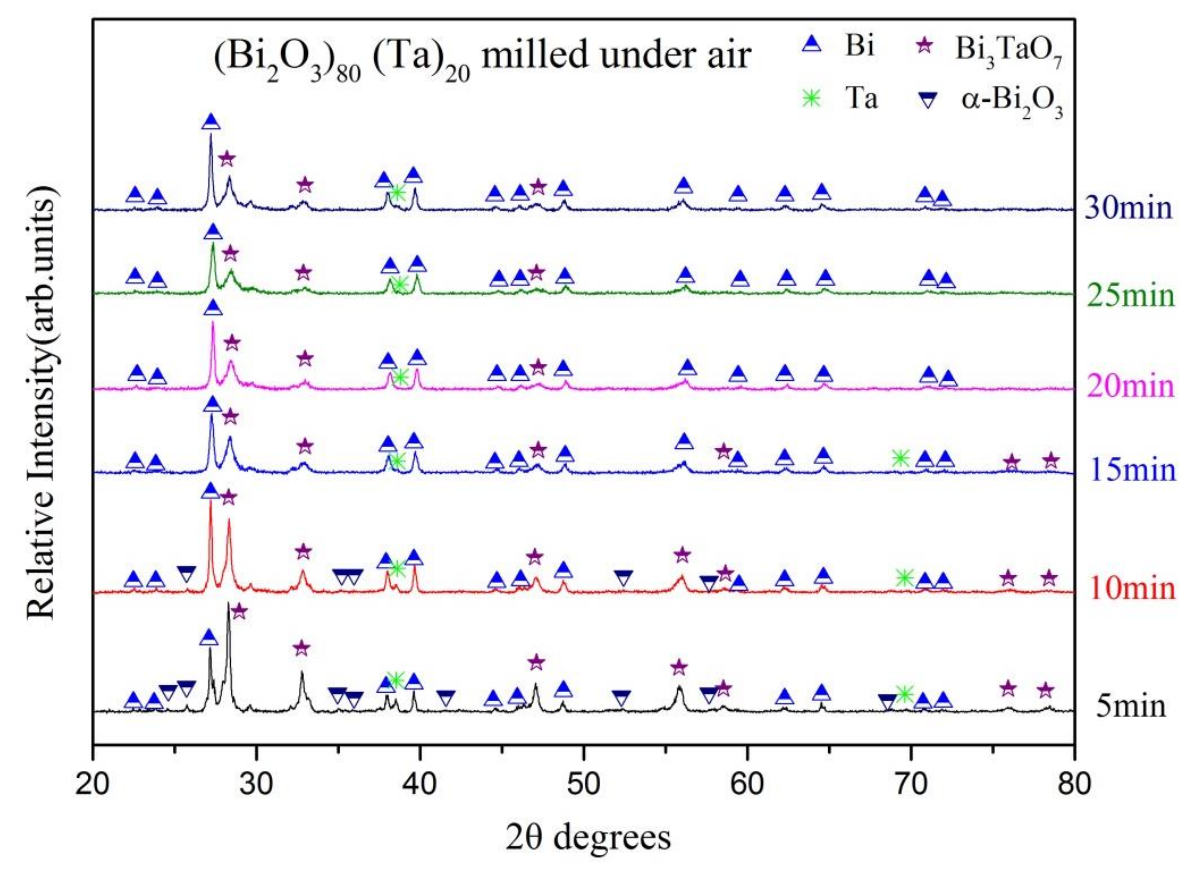

(a)

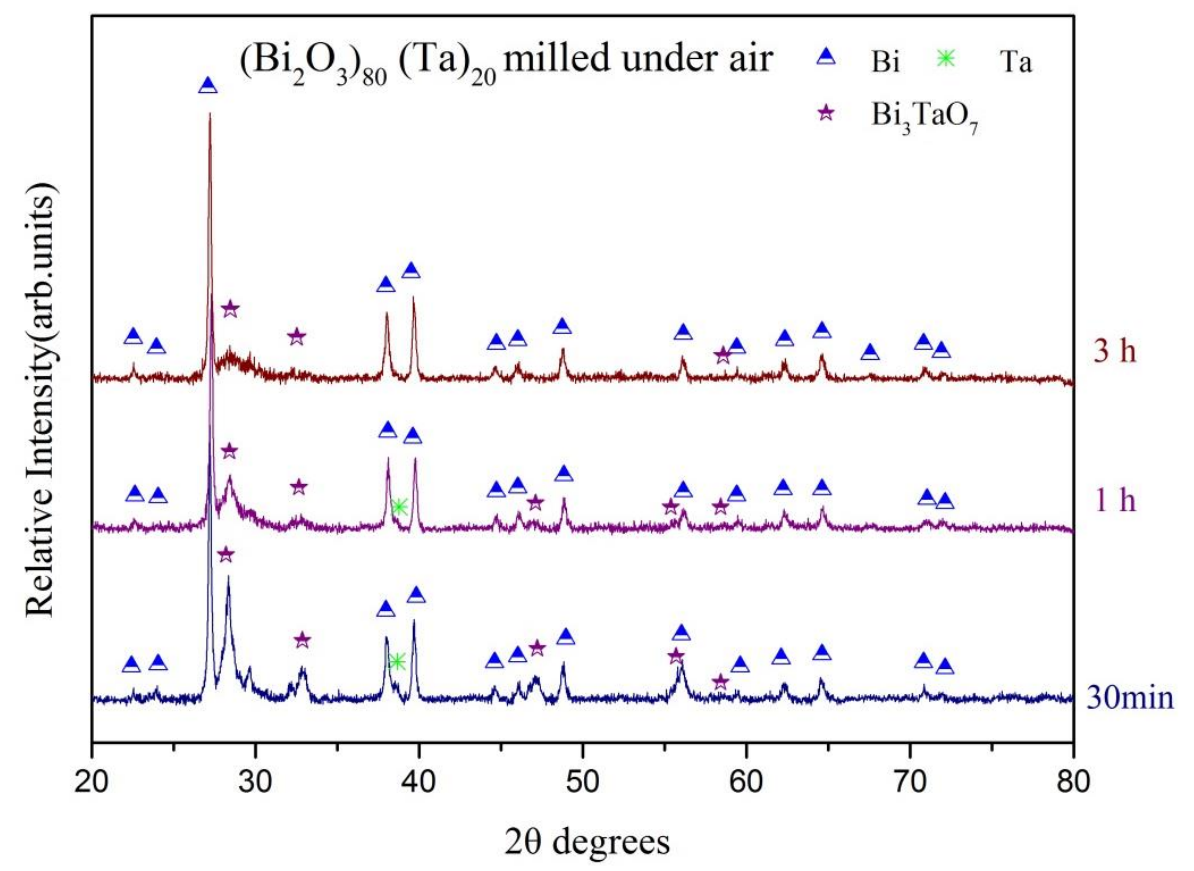

(b)

Figure 6. X-ray diffraction patterns of $\left(\mathrm{Bi}_{2} \mathrm{O}_{3}\right)_{80} \mathrm{Ta}_{20}$ as a function of milling time under air. (a) early stages of milling and (b) long-term milling.

In order to further reveal the phase transition during ball milling process, the XRD results were analyzed by Rietveld fitting method. Table 1 summarizes the phase transitions and the corresponding phase percentages of $\left(\mathrm{Bi}_{2} \mathrm{O}_{3}\right)_{80}(\mathrm{Ta})_{20}$ powder at various milling stages during high energy ball milling under either glove box or ambient atmosphere conditions. Figure 7 shows the percentage of individual phase as a function of milling time. As shown in Figure $7 \mathrm{a}$ for $\left(\mathrm{Bi}_{2} \mathrm{O}_{3}\right)_{80}(\mathrm{Ta})_{20}$ powder milled under Ar-filled glove box conditions, the starting powders, $\alpha-\mathrm{Bi}_{2} \mathrm{O}_{3}$ and $\mathrm{Ta}$, transformed into $\alpha-\mathrm{Bi}_{2} \mathrm{O}_{4}$, bismuth, and $\delta-\mathrm{Bi}_{3} \mathrm{TaO}_{7}$ phases. The relative percentage of $\alpha-\mathrm{Bi}_{2} \mathrm{O}_{4}$ remained $\sim 8$ to $9 \%$ after $10 \mathrm{~min}$ of milling and did not show significant difference thereafter. The percentage of Ta was $15.4 \%$ after 
5 min of milling, decreased to $2.5 \%$ at 10 min milling, and fluctuated around $1.4 \%$ to $3.1 \%$ through the milling process. A gradual increase of bismuth from $23.4 \%$ (10 min of milling) to $69.7 \%$ ( $3 \mathrm{~h}$ of milling) can be observed. The relative amount of $\delta-\mathrm{Bi}_{3} \mathrm{TaO}_{7}$ phase, however, reached a maximum of $52.8 \%$ after $10 \mathrm{~min}$ of milling and gradually decreased to $18.8 \%$ after $3 \mathrm{~h}$ of milling treatment. Figure $7 \mathrm{~b}$ shows the percentage of individual phase for $\left(\mathrm{Bi}_{2} \mathrm{O}_{3}\right)_{80}(\mathrm{Ta})_{20}$ powder milled under ambient atmosphere conditions. Similar behavior can be noticed as those shown in Figure 7a, except for the accelerated mechanochemical reaction after 5 min of milling.

Table 1. Crystalline phases of $\left(\mathrm{Bi}_{2} \mathrm{O}_{3}\right)_{80} \mathrm{Ta}_{20}$ as a function of milling time under different oxygen environments.

\begin{tabular}{|c|c|c|}
\hline Milling Condition & Milling Time & Crystalline Phases \\
\hline \multirow{8}{*}{ Inside Ar-filled glove box } & $5 \mathrm{~min}$ & $\alpha-\mathrm{Bi}_{2} \mathrm{O}_{3}(84.6 \%)^{*}+\mathrm{Ta}(15.4 \%)$ \\
\hline & $10 \mathrm{~min}$ & $\alpha-\mathrm{Bi}_{2} \mathrm{O}_{4}(8.1 \%)+\alpha-\mathrm{Bi}_{2} \mathrm{O}_{3}(13.2 \%)+\mathrm{Bi}(23.4 \%)+\delta-\mathrm{Bi}_{3} \mathrm{TaO}_{7}(52.8 \%)+\mathrm{Ta}(2.5 \%)$ \\
\hline & $15 \mathrm{~min}$ & $\alpha-\mathrm{Bi}_{2} \mathrm{O}_{4}(8.3 \%)+\alpha-\mathrm{Bi}_{2} \mathrm{O}_{3}(3.8 \%)+\mathrm{Bi}(44.4 \%)+\delta-\mathrm{Bi}_{3} \mathrm{TaO}_{7}(41.5 \%)+\mathrm{Ta}(2.0 \%)$ \\
\hline & $20 \min$ & $\alpha-\mathrm{Bi}_{2} \mathrm{O}_{4}(8.7 \%)+\mathrm{Bi}(47.8 \%)+\delta-\mathrm{Bi}_{3} \mathrm{TaO}_{7}(41.4 \%)+\mathrm{Ta}(2.0 \%)$ \\
\hline & $25 \mathrm{~min}$ & $\alpha-\mathrm{Bi}_{2} \mathrm{O}_{4}(8.7 \%)+\mathrm{Bi}(49.9 \%)+\delta-\mathrm{Bi}_{3} \mathrm{TaO}_{7}(40.0 \%)+\mathrm{Ta}(1.4 \%)$ \\
\hline & $30 \mathrm{~min}$ & $\alpha-\mathrm{Bi}_{2} \mathrm{O}_{4}(8.2 \%)+\mathrm{Bi}(52.9 \%)+\delta-\mathrm{Bi}_{3} \mathrm{TaO}_{7}(37.4 \%)+\mathrm{Ta}(1.5 \%)$ \\
\hline & $1 \mathrm{~h}$ & $\alpha-\mathrm{Bi}_{2} \mathrm{O}_{4}(8.8 \%)+\mathrm{Bi}(60.3 \%)+\delta-\mathrm{Bi}_{3} \mathrm{TaO}_{7}(28.6 \%)+\mathrm{Ta}(2.3 \%)$ \\
\hline & $3 \mathrm{~h}$ & $\alpha-\mathrm{Bi}_{2} \mathrm{O}_{4}(9.4 \%)+\mathrm{Bi}(69.7 \%)+\delta-\mathrm{Bi}_{3} \mathrm{TaO}_{7}(18.8 \%)+\mathrm{Ta}(3.1 \%)$ \\
\hline \multirow{8}{*}{ Under air } & $5 \mathrm{~min}$ & $\alpha-\mathrm{Bi}_{2} \mathrm{O}_{4}(5.5 \%)+\alpha-\mathrm{Bi}_{2} \mathrm{O}_{3}(13.0 \%)+\mathrm{Bi}(21.2 \%)+\delta-\mathrm{Bi}_{3} \mathrm{TaO}_{7}(58.7 \%)+\mathrm{Ta}(1.6 \%)$ \\
\hline & $10 \mathrm{~min}$ & $\alpha-\mathrm{Bi}_{2} \mathrm{O}_{4}(4.5 \%)+\alpha-\mathrm{Bi}_{2} \mathrm{O}_{3}(10.0 \%)+\mathrm{Bi}(33.8 \%)+\delta-\mathrm{Bi}_{3} \mathrm{TaO}_{7}(50.5 \%)+\mathrm{Ta}(1.2 \%)$ \\
\hline & $15 \mathrm{~min}$ & $\alpha-\mathrm{Bi}_{2} \mathrm{O}_{4}(5.3 \%)+\mathrm{Bi}(39.5 \%)+\delta-\mathrm{Bi}_{3} \mathrm{TaO}_{7}(54.5 \%)+\mathrm{Ta}(0.7 \%)$ \\
\hline & $20 \mathrm{~min}$ & $\alpha-\mathrm{Bi}_{2} \mathrm{O}_{4}(3.0 \%)+\mathrm{Bi}(38.0 \%)+\delta-\mathrm{Bi}_{3} \mathrm{TaO}_{7}(58.6 \%)+\mathrm{Ta}(0.4 \%)$ \\
\hline & $25 \min$ & $\alpha-\mathrm{Bi}_{2} \mathrm{O}_{4}(1.8 \%)+\mathrm{Bi}(42.0 \%)+\delta-\mathrm{Bi}_{3} \mathrm{TaO}_{7}(54.1 \%)+\mathrm{Ta}(2.1 \%)$ \\
\hline & $30 \mathrm{~min}$ & $\alpha-\mathrm{Bi}_{2} \mathrm{O}_{4}(5.1 \%)+\mathrm{Bi}(52.8 \%)+\delta-\mathrm{Bi}_{3} \mathrm{TaO}_{7}(40.6 \%)+\mathrm{Ta}(1.5 \%)$ \\
\hline & $1 \mathrm{~h}$ & $\alpha-\mathrm{Bi}_{2} \mathrm{O}_{4}(2.9 \%)+\mathrm{Bi}(56.0 \%)+\delta-\mathrm{Bi}_{3} \mathrm{TaO}_{7}(40.3 \%)+\mathrm{Ta}(0.8 \%)$ \\
\hline & $3 \mathrm{~h}$ & $\alpha-\mathrm{Bi}_{2} \mathrm{O}_{4}(2.7 \%)+\mathrm{Bi}(71.9 \%)+\delta-\mathrm{Bi}_{3} \mathrm{TaO}_{7}(25.4 \%)$ \\
\hline
\end{tabular}

Note: *: the percentage of individual phase is given in the bracket

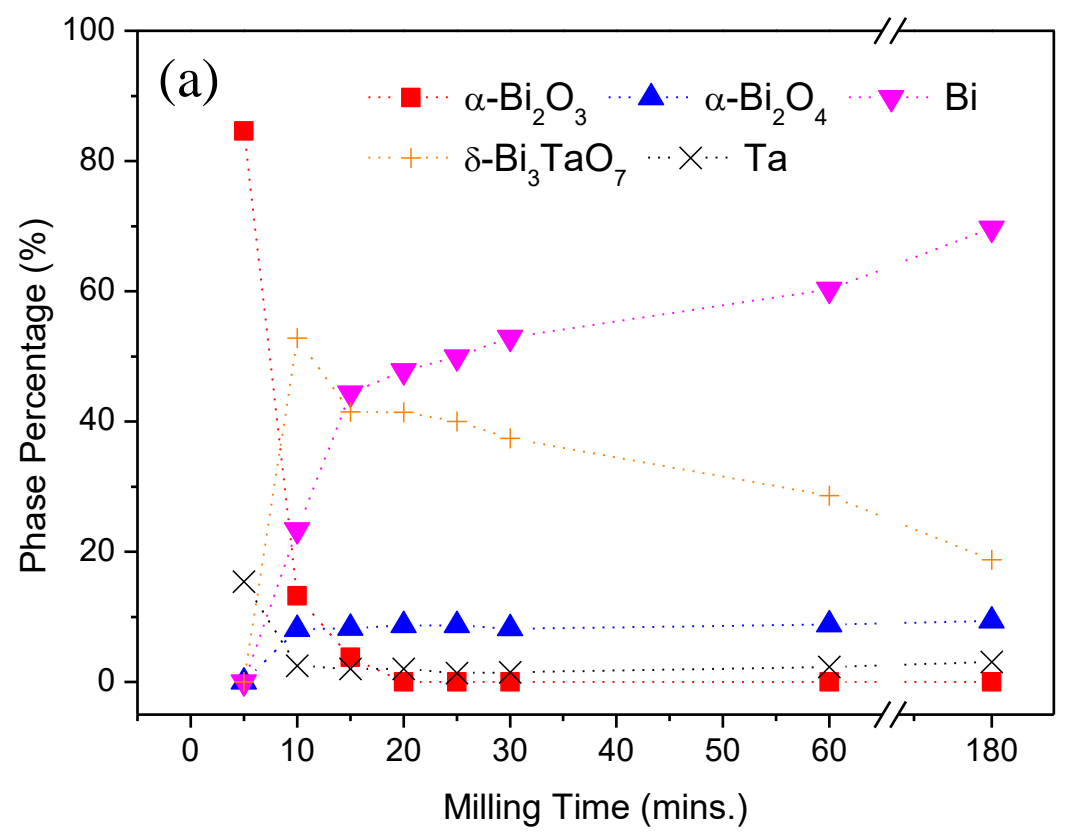

Figure 7. Cont. 


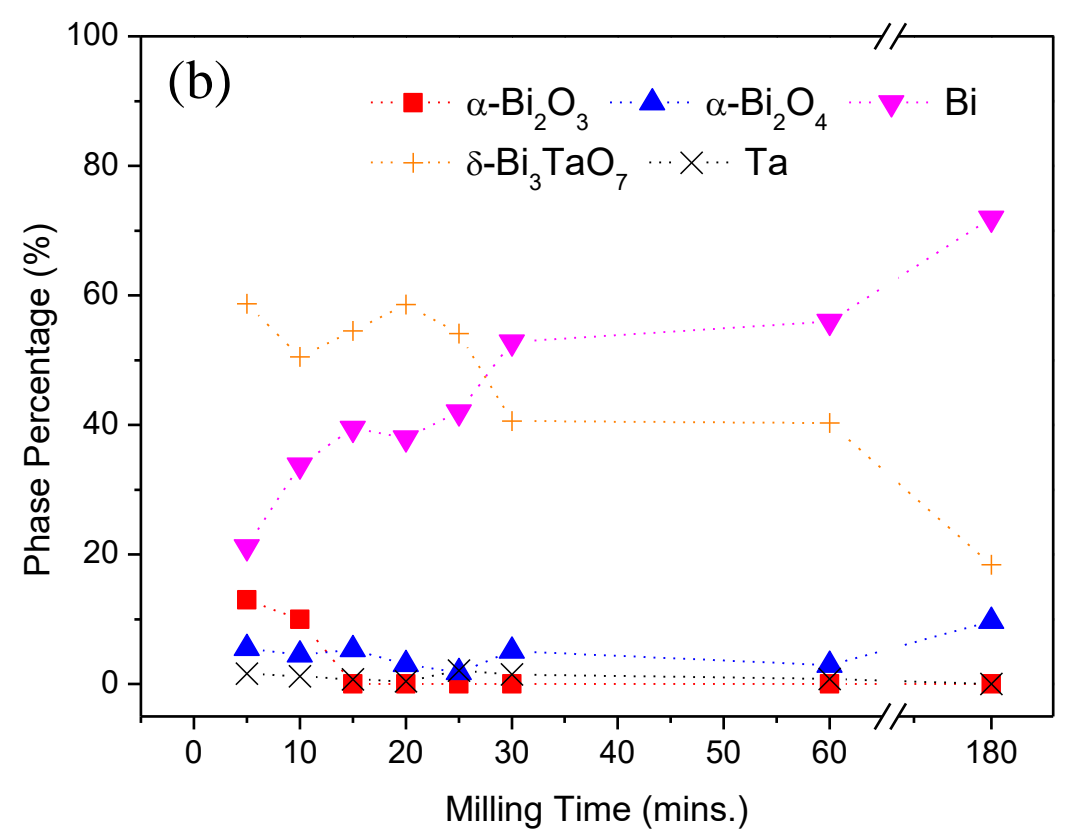

Figure 7. The percentage of individual phase as a function of milling time under (a) Ar-filled glove box conditions and (b) air.

Though not shown here, cross-sectional examination of as-milled $\left(\mathrm{Bi}_{2} \mathrm{O}_{3}\right)_{80}(\mathrm{Ta})_{20}$ powder under ambient atmosphere showed widely distributed irregular grains at all milling stages and did not reveal significant differences from those milled within the glove box (Figure 2). Figure 8 shows the DSC curves of as-milled powder at various stages. The 5-min as-milled powder exhibited an endothermic peak at $273.1^{\circ} \mathrm{C}$, which is slightly higher than the $271.1^{\circ} \mathrm{C}$ melting point of bismuth. This accounts for the existence of bismuth within the 5-mins as-milled powder. After 10-mins of milling, the endothermic peak exhibited a maximum peak height and indicated the reduced bismuth reached a maximum. This confirmed the XRD results discussed in Figure 6. The endothermic peak height decreased with prolonged milling similar to those milled under an Ar-filled glove box environment (Figure 5). DSC examination confirms that the mechanochemical reaction began at a very early stage of milling ( $5 \mathrm{~min}$ ) and continued thereafter throughout the ball milling process.

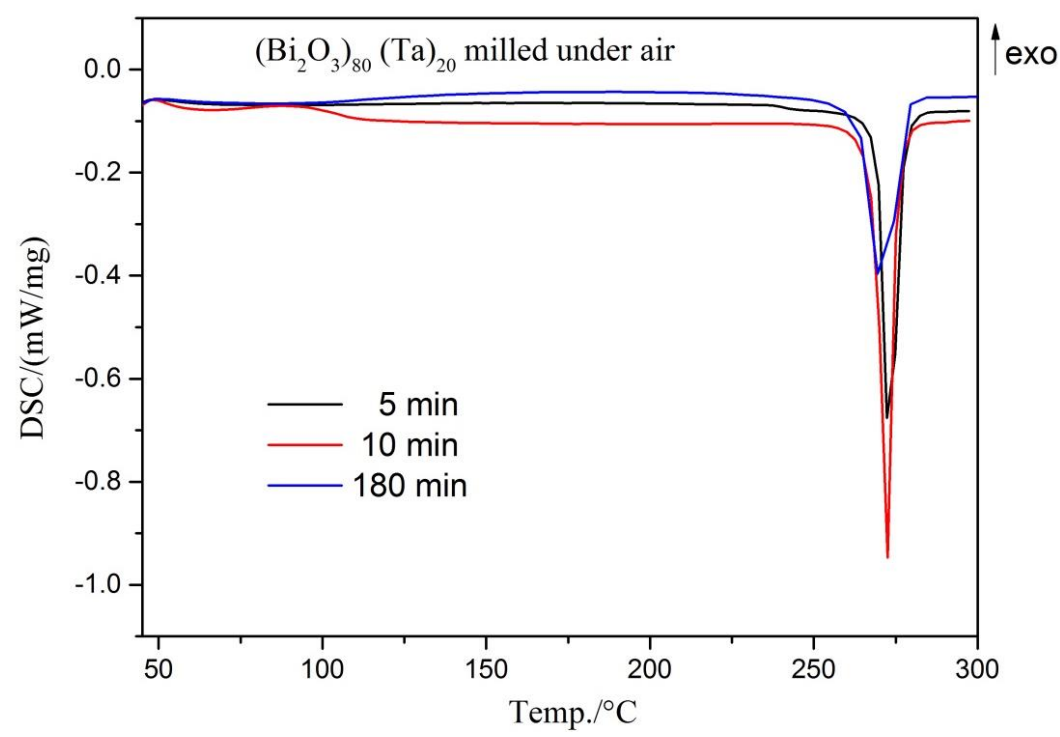

Figure 8. Differential scanning calorimetry (DSC) curves of $\left(\mathrm{Bi}_{2} \mathrm{O}_{3}\right)_{80} \mathrm{Ta}_{20}$ for different milling times under air. 
$\left(\mathrm{Bi}_{2} \mathrm{O}_{3}\right)_{80}(\mathrm{Ta})_{20}$ powders milled within either the glove box or ambient environments were used to investigate the effects of oxygen concentration. Additionally, to determine the influence of tantalum addition, the amount of tantalum was decreased to $5 \mathrm{wt} \%$ and high-energy ball milling was executed within a glove box. Figure 9 shows the $\mathrm{X}$-ray diffraction patterns of the as-milled $\left(\mathrm{Bi}_{2} \mathrm{O}_{3}\right)_{95}(\mathrm{Ta})_{5}$ powders at various milling stages. With a limited amount of tantalum addition, the superfluous reactant $\alpha-\mathrm{Bi}_{2} \mathrm{O}_{3}$ phase persisted for up to three hours of milling. The crystalline peaks of tantalum were observed after one hour of milling. A new crystalline phase of tetragonal $\beta-\mathrm{Bi}_{7.8} \operatorname{Ta}_{0.2} \mathrm{O}_{12.2}$ (ICDD PDF card No. 043-0451) was observed after $30 \mathrm{~min}$ of milling. During the three hours of milling, bismuth was not reduced, and tantalum was continuously merged into the $\alpha-\mathrm{Bi}_{2} \mathrm{O}_{3}$ phase, which induced the formation of $\beta-\mathrm{Bi}_{7.8} \mathrm{Ta}_{0.2} \mathrm{O}_{12.2}$ phase. When the milling time was increased to $10 \mathrm{~h}$, the crystalline peaks of the starting powders $\alpha-\mathrm{Bi}_{2} \mathrm{O}_{3}$ and Ta disappeared, whereas the peak heights of $\beta-\mathrm{Bi}_{7.8} \mathrm{Ta}_{0.2} \mathrm{O}_{12.2}$ phase increased, and diffraction peaks of newly-formed bismuth were observed. Table 2 summarizes the corresponding crystalline phases and relative phase percentages at various milling stages of $\left(\mathrm{Bi}_{2} \mathrm{O}_{3}\right)_{95}(\mathrm{Ta})_{5}$ powders. The relative amounts of individual phases can be observed better in Figure 10, in which $\alpha-\mathrm{Bi}_{2} \mathrm{O}_{3}$ was $56.0 \%$ after $30 \mathrm{~min}$ of milling, and the amount decreased with increasing milling time and became indistinguishable at the end of milling $(10 \mathrm{~h})$. The amount of 30-min as-milled $\beta-\mathrm{Bi}_{7.8} \mathrm{Ta}_{0.2} \mathrm{O}_{12.2}$ phase was $41.6 \%$, which gradually increased with increasing milling time and reached $90.8 \%$ after $10 \mathrm{~h}$ of milling. In addition, the diffraction peaks of Ta disappeared after three hours of milling and the formation of bismuth was observed after $10 \mathrm{~h}$ milling.

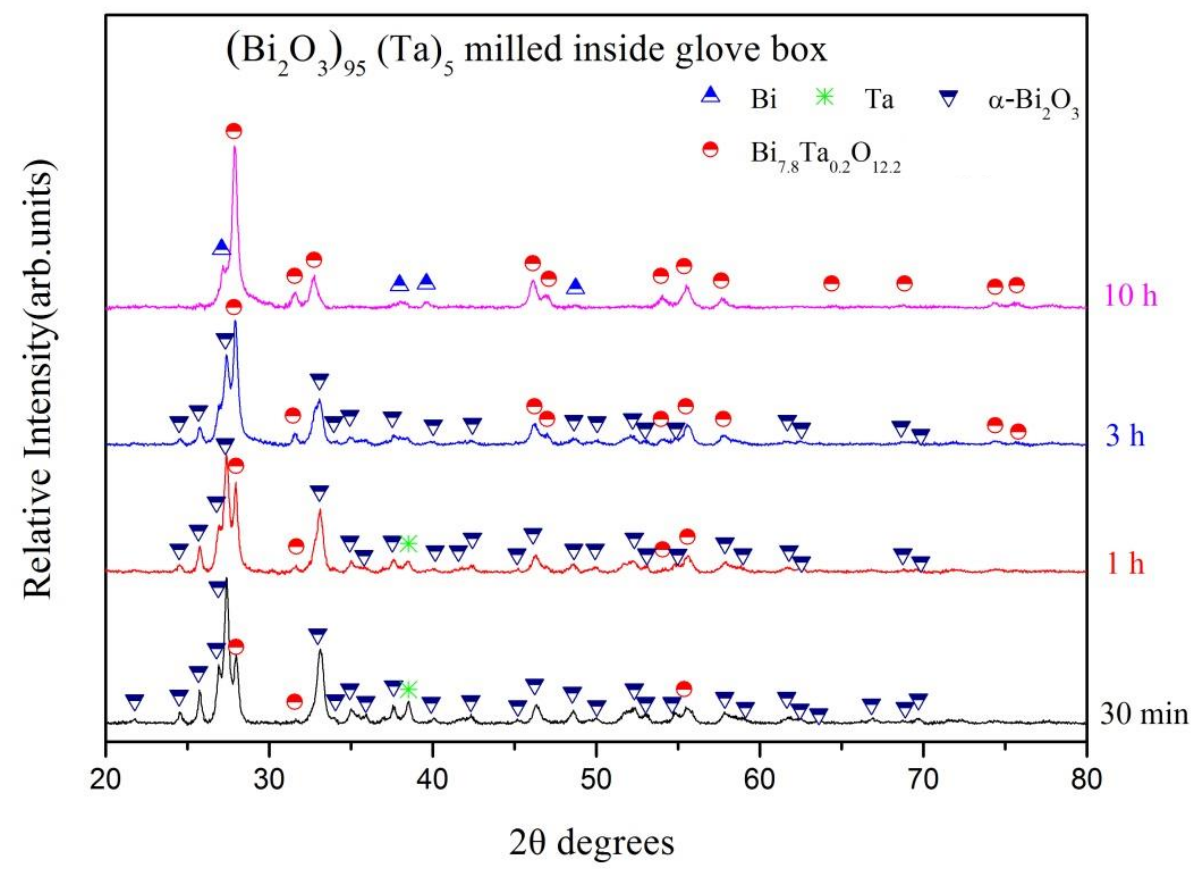

Figure 9. X-ray diffraction patterns of $\left(\mathrm{Bi}_{2} \mathrm{O}_{3}\right)_{95} \mathrm{Ta}_{5}$ after different milling times under Ar-filled glove box conditions.

Table 2. Crystalline phases of $\left(\mathrm{Bi}_{2} \mathrm{O}_{3}\right)_{95} \mathrm{Ta}_{5}$ as a function of milling time under Ar-filled glove box conditions.

\begin{tabular}{|c|c|c|}
\hline Milling Condition & Milling Time & Crystalline Phases \\
\hline \multirow{4}{*}{ Inside Ar-filled glove box } & $30 \mathrm{~min}$ & $\alpha-\mathrm{Bi}_{2} \mathrm{O}_{3}(56.0 \%)^{*}+\mathrm{Ta}(2.4 \%)+\beta-\mathrm{Bi}_{7.8} \mathrm{Ta}_{0.2} \mathrm{O}_{12.2}(41.6 \%)$ \\
\hline & $1 \mathrm{~h}$ & $\alpha-\mathrm{Bi}_{2} \mathrm{O}_{3}(46.2 \%)+\mathrm{Ta}(1.7 \%)+\beta-\mathrm{Bi}_{7.8} \mathrm{Ta}_{0.2} \mathrm{O}_{12.2}(52.1 \%)$ \\
\hline & $3 \mathrm{~h}$ & $\alpha-\mathrm{Bi}_{2} \mathrm{O}_{3}(32.8 \%)+\beta-\mathrm{Bi}_{7.8} \mathrm{Ta}_{0.2} \mathrm{O}_{12.2}(67.2 \%)$ \\
\hline & $10 \mathrm{~h}$ & $\beta-\mathrm{Bi}_{7.8} \mathrm{Ta}_{0.2} \mathrm{O}_{12.2}(90.8 \%)+\mathrm{Bi}(9.2 \%)$ \\
\hline
\end{tabular}

Note: * the percentage of the individual phase is provided in the bracket. 


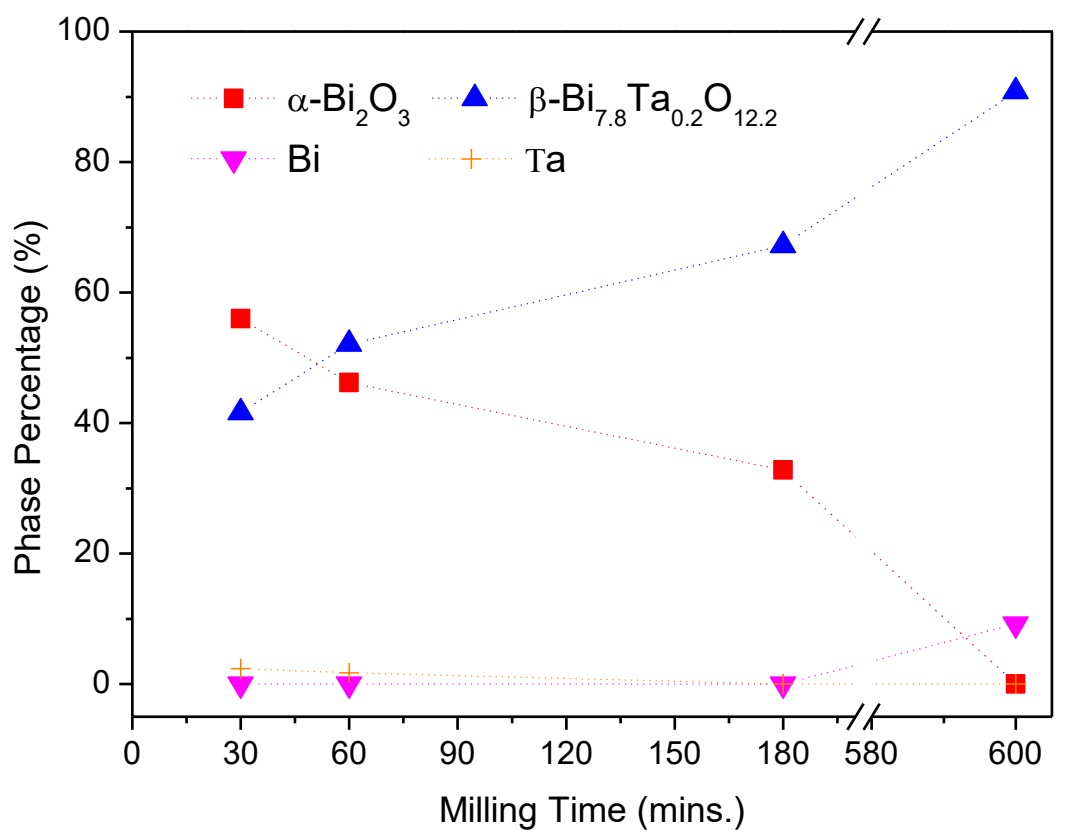

Figure 10. The percentage of individual phase of $\left(\mathrm{Bi}_{2} \mathrm{O}_{3}\right)_{95} \mathrm{Ta}_{5}$ after different milling times under Ar-filled glove box conditions.

The starting powder, $\alpha-\mathrm{Bi}_{2} \mathrm{O}_{3}$, exhibits a monoclinic structure that is stable at room temperature. Unlike $\alpha-\mathrm{Bi}_{2} \mathrm{O}_{3}, \delta-\mathrm{Bi}_{2} \mathrm{O}_{3}$ is fluorite-like cubic structure that is stable at high temperatures $\left(730-825^{\circ} \mathrm{C}\right)$. During phase transformation, two intermediate metastable phases, which are either a tetragonal $\beta$ phase or a body-centered cubic $\gamma$ phase, can be observed. In the present study, for the $\left(\mathrm{Bi}_{2} \mathrm{O}_{3}\right)_{95}(\mathrm{Ta})_{5}$ powder mixture milled under glove box conditions, tantalum slowly but continuously reacted with $\alpha-\mathrm{Bi}_{2} \mathrm{O}_{3}$ phase and formed tetragonal $\beta-\mathrm{Bi}_{7.8} \mathrm{Ta}_{0.2} \mathrm{O}_{12.2}$ phase. When $\left(\mathrm{Bi}_{2} \mathrm{O}_{3}\right)_{80}(\mathrm{Ta})_{20}$ was milled under glove box conditions, the mechanochemical reaction began after $10 \mathrm{~min}$ of high-energy ball milling and formation of fluorite-like $\delta-\mathrm{Bi}_{3} \mathrm{TaO}_{7}$ was observed. By milling under ambient environment conditions, the oxygen concentration was higher, allowing the mechanochemical reaction to accelerate, which triggered the reaction within less than five minutes of milling.

\section{Conclusions}

By milling $\left(\mathrm{Bi}_{2} \mathrm{O}_{3}\right)_{80}(\mathrm{Ta})_{20}$ and $\left(\mathrm{Bi}_{2} \mathrm{O}_{3}\right)_{95}(\mathrm{Ta})_{5}$ compositions, high-temperature fluorite-like phases were prepared using a mechanochemical reaction. By milling $\left(\mathrm{Bi}_{2} \mathrm{O}_{3}\right)_{95}(\mathrm{Ta})_{5}$ powder mixtures within an Ar-filled glove box, tantalum gradually reacted with $\alpha-\mathrm{Bi}_{2} \mathrm{O}_{3}$ phase and formed $\beta-\mathrm{Bi}_{7.8} \mathrm{Ta}_{0.2} \mathrm{O}_{12.2}$ phase after $10 \mathrm{~min}$ of milling. By increasing tantalum addition to $20 \mathrm{wt} \%$, superfluous Ta can be mechanochemically reacted with $\alpha-\mathrm{Bi}_{2} \mathrm{O}_{3}$ to form $\delta-\mathrm{Bi}_{3} \mathrm{TaO}_{7}$ and bismuth phases after $10 \mathrm{~min}$ of ball milling. The mechanochemical reaction can be shortened to less than five minutes by increasing oxygen concentration (i.e., milling $\left(\mathrm{Bi}_{2} \mathrm{O}_{3}\right)_{80}(\mathrm{Ta})_{20}$ under ambient atmosphere conditions), which resulted in the formation of a high temperature $\delta-\mathrm{Bi}_{3} \mathrm{TaO}_{7}$ phase.

Author Contributions: Conceptualization and Funding acquisition, H.-N.L.; Data curing and Methodology, M.-S.C.; Formal analysis and Investigation, Y.-H.C.; Resources and Supervision, P.-Y.L.; Validification, Writing-Original Draft, Writing-Review \& Editing, C.-K.L.; all co-authors provided their comments to refine the paper.

Funding: This study was supported by CMPR (Grant no: CMRPG1B0011) in Chang Gung Memorial Hospital and partially supported by Ministry of Science and Technology, Taiwan (Grant no: MOST 107-2622-E-038-002 -CC3).

Conflicts of Interest: The authors declare no conflict of interest. 


\section{References}

1. Coomaraswamy, K.S.; Lumley, P.J.; Hofmann, M.P. Effect of bismuth oxide radioopacifier content on the material properties of an endodontic Portland cement-based (MTA-like) system. J. Endod. 2007, 33, $295-298$. [CrossRef] [PubMed]

2. Chen, M.S.; Yang, J.C.; Lai, F.C.; Chen, C.Y.; Hsieh, M.Y.; Fang, A.; Chen, S.H.; Lin, C.K. Radiopacity performances of precipitated $\mathrm{ZrO}_{2}$-doped $\mathrm{Bi}_{2} \mathrm{O}_{3}$ powders and the influences of dopant concentrations and sintering temperatures. Ceram. Int. 2017, 43, 14008-14014. [CrossRef]

3. Chen, M.S.; Chen, S.H.; Lai, F.C.; Chen, C.Y.; Hsieh, M.Y.; Chang, W.J.; Yang, J.C.; Lin, C.K. Sintering temperature-dependence on radiopacity of $\mathrm{Bi}_{(2-\mathrm{x})} \mathrm{Zr}_{\mathrm{x}} \mathrm{O}_{(3+\mathrm{x} / 2)}$ powders prepared by sol-gel process. Materials 2018, 11, 1685. [CrossRef] [PubMed]

4. Shuk, P.; Wiemhofer, H.D.; Guth, U.; Gopel, W.; Greenblatt, M. Oxide ion conducting solid electrolytes based on $\mathrm{Bi}_{2} \mathrm{O}_{3}$. Solid State Ion. 1996, 89, 179-196. [CrossRef]

5. Weng, C.H.; Wei, W.C.J. Synthesis and Properties of Homogeneous Nb-Doped Bismuth Oxide. J. Am. Ceram. Soc. 2010, 93, 3124-3129. [CrossRef]

6. Fruth, V.; Ianculescu, A.; Berger, D.; Preda, S.; Voicu, G.; Tenea, E.; Popa, M. Synthesis, structure and properties of doped $\mathrm{Bi}_{2} \mathrm{O}_{3}$. J. Eur. Ceram. Soc. 2006, 26, 3011-3016. [CrossRef]

7. Wu, Y.S.; Hou, J.; Gong, Z.; Miao, L.N.; Tang, H.D.; Liu, W. High performance $\mathrm{BaCe}_{0.5} \mathrm{Fe}_{0.5-\mathrm{x}} \mathrm{Bi}_{\mathrm{x}} \mathrm{O}_{3}$-delta as cobalt-free cathode for proton-conducting solid oxide fuel cells. J. Alloy. Compd. 2019, 790, 551-557. [CrossRef]

8. Wang, J.; Chen, X.; Xie, S.; Chen, L.; Wang, Y.; Meng, J.; Zhou, D. Bismuth tungstate/neodymium-doped ceria composite electrolyte for intermediate-temperature solid oxide fuel cell: Sintering aid and composite effect. J. Power Sources 2019, 428, 105-114. [CrossRef]

9. Aurivillius, B.; Sillen, L.G. Polymorphy of bismuth trioxide. Nature 1945, 155, 305-306. [CrossRef]

10. Harwig, H.A.; Gerards, A.G. The polymorphism of bismuth sesquioxide. Thermochim. Acta 1979, 28, 121-131. [CrossRef]

11. Zhou, W. Structural chemistry and physical properties of some ternary oxides in the $\mathrm{Bi}_{2} \mathrm{O}_{3}-\mathrm{Ta}_{2} \mathrm{O}_{5}$ system. J. Solid State Chem. 1992, 101,1-17. [CrossRef]

12. Jardiel, T.; Calatayud, D.G.; Rodríguez, M.; Fernández-Hevia, D.; Caballero, A.C. Synthesis of metastable $\mathrm{Bi}_{6} \mathrm{Ti}_{5} \mathrm{WO}_{22}$ phase by the mechanochemical method. Mater. Lett. 2013, 94, 58-60. [CrossRef]

13. Zdujić, M.; Poleti, D.; Jovalekić, Č.; Karanović, L. Mechanochemical synthesis and electrical conductivity of nanocrystalline $\delta-\mathrm{Bi}_{2} \mathrm{O}_{3}$ stabilized by $\mathrm{HfO}_{2}$ and $\mathrm{ZrO}_{2}$. J. Serb. Chem. Soc. 2009, 74, 1401-1411. [CrossRef]

14. Asryan, N.A.; Kol'tsova, T.N.; Alikhanyan, A.S.; Nipan, G.D. Thermodynamics and Phase Diagram of the $\mathrm{Bi}_{2} \mathrm{O}_{3}-\mathrm{SnO}_{2}$ System. Inorg. Mater. 2002, 38, 1141-1147. [CrossRef]

15. Ling, C.D.; Withers, R.L.; Schmid, S.; Thompson, J.G. A Review of Bismuth-Rich Binary Oxides in the Systems $\mathrm{Bi}_{2} \mathrm{O}_{3}-\mathrm{Nb}_{2} \mathrm{O}_{5}, \mathrm{Bi}_{2} \mathrm{O}_{3}-\mathrm{Ta}_{2} \mathrm{O}_{5}, \mathrm{Bi}_{2} \mathrm{O}_{3}-\mathrm{MoO}_{3}$, and $\mathrm{Bi}_{2} \mathrm{O}_{3}-\mathrm{WO}_{3}$. J. Solid State Chem. 1998, 137, 42-61. [CrossRef]

16. Lin, S.E.; Wei, W.C.J. Long-term degradation of $\mathrm{Ta}_{2} \mathrm{O}_{5}$-doped $\mathrm{Bi}_{2} \mathrm{O}_{3}$ systems. J. Eur. Ceram. Soc. 2011, 31, 3081-3086. [CrossRef]

17. Saito, T.; Miida, R. Crystal Structure and Ionic Conductivity in $\mathrm{Bi}_{2} \mathrm{O}_{3}$ - $\mathrm{Rich} \mathrm{Bi}_{2} \mathrm{O}_{3}-\mathrm{Ta}_{2} \mathrm{O}_{5}$ Sintered Oxides. Jpn. J. Appl. Phys. 1999, 38, 4838-4842. [CrossRef]

18. Benjamin, J.S. Mechanical Alloying. Sci. Am. 1976, 234, 40-49. [CrossRef]

19. Murty, B.S.; Ranganathan, S. Novel materials synthesis by mechanical alloying/milling. Int. Mater. Rev. 1998, 43, 101-141. [CrossRef]

20. Suryanarayana, C. Mechanical alloying and milling. Prog. Mater. Sci. 2001, 46,1-184. [CrossRef]

21. Lee, P.Y.; Koch, C.C. Formation of amorphous Ni-Zr alloy powder by mechanical alloying of intermetallic powder mixtures and mixtures of nickel or zirconium with intermetallics. J. Mater. Sci. 1988, 23, 2837-2845. [CrossRef]

22. Koch, C.C.; Whittenberger, J.D. Mechanical milling/alloying of intermetallics. Intermetallics 1996, 4, 339-355. [CrossRef]

23. Tsuzuki, T.; McCormick, P.G. Nanopowders synthesized by mechanochemical processing. J. Mater. Sci. 2004, 39, 5143-5146. [CrossRef]

24. Duan, C.W.; Hu, L.X.; Ma, J.L. Ionic liquids as an efficient medium for the mechanochemical synthesis of $\alpha$-AlH3 nano-composites. J. Mater. Chem. A 2018, 6, 6309-6318. [CrossRef] 
25. Xiao, Z.; Li, X.; Xiao, Q.; Luo, W.; Zhang, H.; Wang, C.; Zhang, T.; Li, S.; Kong, L.B. Bismuth lanthanum titanate ceramics from amorphous precursors activated by using mechanochemical treatment. Ceram. Int. 2018, 44, 13106-13112. [CrossRef]

26. Ding, J.; Miao, W.F.; McCormick, P.G.; Street, R. Mechanochemical synthesis of ultrafine Fe powder. Appl. Phys. Lett. 1995, 67, 3804. [CrossRef]

27. Castro, A.; Palem, D. Study of fluorite phases in the system $\mathrm{Bi}_{2} \mathrm{O}_{3}-\mathrm{Nb}_{2} \mathrm{O}_{5}-\mathrm{Ta}_{2} \mathrm{O}_{5}$. Synthesis by mechanochemical activation assisted methods. J. Mater. Chem. 2002, 12, 2774-2780. [CrossRef]

28. Bandyopadhyay, S.; Dutta, S.; Dutta, A.; Pradhan, S.K. Mechanosynthesis of Nanocrystalline Fully Stabilized bcc $\gamma$-phase of $\mathrm{Bi}_{2} \mathrm{O}_{3}$ without Any Additive: Manifestation of Ferroelasticity in Microstructure, Optical, and Transport Properties. Cryst. Growth Des. 2018, 18, 6564-6572. [CrossRef]

29. Hasanpour, A.; Mozaffari, M.; Amighian, J. Preparation of $\mathrm{Bi}-\mathrm{Fe}_{3} \mathrm{O}_{4}$ nanocomposite through reduction of $\mathrm{Bi}_{2} \mathrm{O}_{3}$ with Fe via high-energy ball milling. Phys. B Condens. Matter 2007, 387, 298-301. [CrossRef]

(C) 2019 by the authors. Licensee MDPI, Basel, Switzerland. This article is an open access article distributed under the terms and conditions of the Creative Commons Attribution (CC BY) license (http://creativecommons.org/licenses/by/4.0/). 